\title{
Evaluation of the Physiological Relationship Between Oxidative Stress and Metabolic Characters: Insights From Hybridization Between Anarhichas minor $\times$ A. lupus
}

\author{
C.M. Gaudreau ${ }^{1 \S}$, N.R. Le François ${ }^{1,2,}$, H. Tveiten ${ }^{3}$ and P.U. Blier ${ }^{1 *}$ \\ ${ }^{1}$ Laboratoire de biologie intégrative, Département de Biologie, Chimie et Géographie, Université du Québec à Rimous- \\ ki, 300 Allée des Ursulines, Rimouski, QC, Canada G5L $3 A 1$ \\ ${ }^{2}$ Division des Collections vivantes et de la recherche, Biodôme de Montréal, 4777, Avenue Pierre-De Coubertin, Mon- \\ tréal, QC H1V $1 B 3$ \\ ${ }^{3}$ Nofima Marine A/S, Muninbakken, Breivika, Tromsø, Norway
}

\begin{abstract}
Physiological indicators such as lipid peroxidation and enzymes involved in aerobic/anaerobic energy metabolism were measured in pure and hybrid lines of wolffish juveniles (Anarhichas minor, $q$ A. minor $\times \hat{\delta}$ A. lupus). Interspecific hybridization was introduced as a powerful tool to promote augmentation of phenotypic variability and consequently improve our capacity for the detection of clear physiological relationships amongst oxidative stress and metabolic characters. Mitochondrial sequence genes analysis between the Atlantic (A. lupus) and spotted wolffish (A. minor) were later performed to further assess the extent of divergence between A. lupus and A. minor mitochondrial haplotypes. The observed divergences $(2.0 \%$ and the number of nonsynonymous substitution $n=23)$ do not seem to be sufficient to generate detectable differences in ETS complexes catalytic capacities. Total LDH activity was however higher in hybrids than in the pure strands and tightly correlated to TBARS levels which suggest that LDH actively participates to the regulation of cellular redox status. Our results are discussed in comparison with a similar study on a charr hybrid (Salvelinus alpinus $\times$ S. fontinalis).
\end{abstract}

Keywords: Anarhichas, comparative sequence analysis, energy metabolism, hybridization, oxidative stress, ROS, spotted wolffish.

\section{INTRODUCTION}

The mitochondrial oxidative phosphorylation (OXPHOS) is an essential pathway where energy is produced through a succession of linked redox reactions. This energy production critically depends on nuclear-mitochondrial interactions as essential OXPHOS peptides encoded by the mitochondrial genome interact directly with those encoded by the nuclear genome. The mitochondrial and nuclear genes are believed to coadapt to each other in synchrony throughout evolution to enable an efficient mitochondrial respiration process (reviewed by [1]). In hybrid organisms, the contribution of both species to the nuclear or mitochondrial genome may expose functional incompatibilities between genomes that have not coevolved together. Since NADH dehydrogenase (Complex I), cytochrome $b c_{1}$ (Complex III), cytochrome $c$ oxidase (Complex IV) and ATP synthase (ComplexV) rely on this unique coevolutionary challenge, incompatibility of nuclear

*Address correspondence to this author at the Université du Québec à Rimouski, 300 Allée des Ursulines, Rimouski, QC, Canada G5L 3A1;

Tel: 1-418-723-1986 ext. 1852, Fax: 1-418-724-1849

E-mail: Pierre_Blier@uqar.qc.ca;

${ }^{\S}$ Both authors contribute equally and mitochondrial genomes can induce metabolic limitations through catalytic or regulatory impairments. These mitochondrial dysfunctions can generate a reduction of hybrid fitness and may pose an intrinsic post-zygotic isolating barrier for populations or species having strong genetic divergence [2]. Impairment of aerobic capacity was shown in interpopulation hybrids of copepod [2, 3] and in murid xenomitochondrial cybrid cell lines [4]. By creating a panel of nuclear-mitochondrial DNA combinations from progressively more divergent murid species, McKenzie et al. [4] suggested an increase of mitochondrial functional impairment with phylogenetic distance. Previous studies on enzyme evolution suggest that only few amino acids substitutions can lead to significant modifications of kinetic properties [5] but recent analysis of nuclear/mitochondrial interactions on respiratory-chain functions suggest that disruption could be apparent only when a certain degree of divergence is reached [6].

The electron transport system (ETS) is an important source of reactive oxygen species (ROS) [7]. ROS target and oxidize the cell's macromolecules. According to the mitochondrial free radical theory of aging, ROS production will increase with age and affect the lifespan of the organism [8-10]. The term "oxidative stress" is used for states where 
the balance between generation and elimination of ROS by the antioxidant system is disturbed in favour of the former [11]. One of the biochemical perturbations resulting from oxidative stress is lipid peroxidation leading to reactive aldehydes such as malondialdehyde (MDA) and lipid peroxide $(\mathrm{LOOH})[12,13]$. Since ROS production depends on the proton gradient and electron flow rate between complexes [14], impairments in mitochondrial respiration potentially induced by hybridization, could result in an enhanced production of ROS in mitochondria.

The Atlantic and spotted wolffish (Anarhichas lupus Linnaeus and Anarhichas minor Olafsen) are arctic-boreal bottom-dwelling fish species distributed in the North Atlantic Ocean. Since both species are the focus of aquaculture research $[15,16]$, rearing procedures are well understood and their large hatchlings $(20-24 \mathrm{~mm}$ at hatching) enables various measurements in a single individual. Moreover, the complete mitochondrial DNA (mtDNA) genome sequences of three wolffish species (Anarhichas spp.) were recently published [17] as a contribution to the recovery plan for the reestablishment of wolffishes in the east of Canada [18]. Indeed, the phylogenetic relationships among Anarhichas species mtDNA indicate that A. minor and A. lupus are each other's closest relative. Their respective mitochondrial genome comprises 16520 and 16519 base pairs, among which there are 283 single nucleotide polymorphisms (SNPs) [17]. Some of these nucleotide substitutions between the three Anarhichas species lead to amino acid replacements in genes encoding peptides involved in the ETS and ATP synthase. Despite these divergences, the occurrence of wolffish hybrids has been suggested in the North Atlantic Ocean [19-22] and a recent complementary study has demonstrated that the Atlantic and spotted wolffish can be hybridised in captivity to produce viable offspring, which suggests no prezygotic isolation between both species [23]. Considering the potential existence of a divergence threshold above which hybrid breakdown is detected, more precise mitochondrial gene sequences analyses are required as well as further assessment of the impacts of amino acid substitutions on metabolic functions and ROS production.

In this study, we performed a comparative sequence analysis of mitochondrial genes of Atlantic and spotted wolffish to identify the distribution of mutational differences across both genomes by exploring the results of Johnstone et al. [17]. These data were used to scrutinize potential impairment of mitochondrial functions that could result in mito-nuclear coadaptations breakdown, leading to disruption of redox equilibrium and fostering oxidative stress. We hypothesized that access to pure and hybrids stocks would allow spreading of metabolic characters thus improving the association of key metabolic phenotype (for example enzyme activities) to redox status of the organisms. These results are also important because they could establish ROS regulation impairment as a potential cause for reproductive isolation between closely related species. We measured the activity of key metabolic enzymes involved in the anaerobic and aerobic metabolism (citric acid cycle and ETS) as well as a product of lipid peroxidation (TBARS) in spotted wolffish and its hybrid with Atlantic wolffish (ㅇ A. minor $\mathrm{X}$ o A. lupus) reared from 0 to 90 days post-hatching (DPH) at the parental species respective optimal growth temperatures; 7-8 ${ }^{\circ} \mathrm{C}$ for $A$. minor and $10-11^{\circ} \mathrm{C}$ for A. lupus $[24,25]$.

\section{MATERIALS AND METHODOLOGY}

\section{mtDNA Sequence Analysis}

Nucleotide sequences of mitochondrial genes from Atlantic wolffish (GenBank accession no. EF427916) and spotted wolffish (GenBank accession no. EF427917) were aligned with BioEdit Sequence Alignment Editor (version 7.0.9.0) [26]. The sequence comparisons, including nucleotide differences, synonymous substitutions and total amino acid differences, were carried out with MEGA (version 1.01) [27]. Nonconservative amino acids substitutions, i.e., the replacement of one amino acid by another belonging to a different amino acid class, were also quantified.

\section{Fish Lines and Rearing Conditions}

Three crosses were made (S1, pure A. minor; $\mathrm{SH} 1$ and $\mathrm{SH} 2$, + A. minor $\times \widehat{\varnothing}$ A. lupus hybrid) and originated from wild captive broodstock of spotted and Atlantic wolffish aged between 9-13 years old, held at the facilities of the Centre Aquacole Marin (QC, Canada) and were produced by artificial fertilization [28]. All families were obtained by crossing the female broodstock fishes $(\mathrm{n}=3)$ with two different males to secure fertilization success and obtain unrelated families. Fertilized eggs were incubated for approximately 1000 degree days in modified Heath tray incubators at $6.0 \pm$ $0.2^{\circ} \mathrm{C}$. Hybrid and pure status assessment were conducted on the different crosses based on a previous publication using the same experimental fish [23] and routine procedures conducted on the broodstock populations from wild origin.

Immediately after hatching, triplicates of all crosses (families) were gradually acclimated (over 2 days) in two independent recirculating rearing systems (Aquabiotech inc., QC, Canada) held at 8 and $10^{\circ} \mathrm{C}$ (optimal temperature for growth of parental species $A$. minor and $A$. lupus respectively) for a period of 90 days $(3 \times 150=450$ fish per species per temperature). Fishes were fed enriched Artemia nauplii for the first two weeks post-hatching and weaned on a marine fish feed formulae (Gemma Skretting Canada, N.-B., Canada). Early-growth and mortality levels were previously fully assessed [see 23].

Tissue preparation Six individuals per replicate were randomly sampled at hatching and at 30 and $90 \mathrm{DPH}$, weighed, measured and preserved at $-80{ }^{\circ} \mathrm{C}$ for physiological measurements. Fish were fasted for 15 hours before sampling and were killed by lethal dose of anaesthetics (Benzocaine) $\geq 80 \mathrm{mg} \mathrm{l}^{-1}$. (Université du Québec à Rimouski (UQAR) local ethics committee and funding agency reviewed the project prior to its realization in governmental facilities (Centre Aquacole marin operated by the Ministère de l'agriculture, des pêcheries et de l'alimentation du Québec (MAPAQ)). Whole individuals were homogenised in nine volumes of ice-cold buffer ( $50 \mathrm{mmol} \mathrm{l}^{-1}$ imidazole, $2 \mathrm{mmol} \mathrm{l}^{-1}$ $\mathrm{MgCl}_{2}, 5 \mathrm{mmol} \mathrm{l}^{-1}$ EDTA and $0.09 \%$ Triton X-100, pH 7.5) for three $10 \mathrm{sec}$ periods (with $1 \mathrm{~min}$ on ice between) with an Ultra Turrax T25 (IKA labortechnik, DE, USA). All manipulations were performed on ice. A first aliquot of the homogenate was centrifuged at $400 \mathrm{~g}$ for $1 \mathrm{~min}$ and a second was centrifuged at $400 \mathrm{~g}$ for $10 \mathrm{~min}$. The supernatant from 
Table 1. Substrates and Buffer Used for Enzyme Analysis

\begin{tabular}{|c|c|c|c|c|}
\hline Enzyme & Substrate & Buffer Solution & pH \\
\hline \hline CS & Oxaloacetate $(0.15 \mathrm{mM})$ & Imidazole-HCl $(100 \mathrm{mM})$ & 8.0 & Thibeault et al. (1997) \\
\hline LDH & Pyruvate $(0.4 \mathrm{mM})$ & Phosphate $(100 \mathrm{mM})$ & 7.0 & Thibeault et al. (1997) \\
\hline CI-III & INT $(2 \mathrm{mM})$ & Potassium-phosphate-sodium $(100 \mathrm{mM})$ & 8.5 & Lannig et al. $(2003)$ \\
\hline CIV & Cytochrome c $(100 \mu \mathrm{M})$ & Potassium-phosphate $(100 \mathrm{mM})$ & 8.0 & Pelletier et al. (1993) \\
\hline
\end{tabular}

the first aliquot was afterwards separated in four sub-aliquots of $100 \mu \mathrm{l}$ : two kept on ice for immediate citrate synthase (CS, EC 2.3.3.1) and lactate dehydrogenase (LDH, EC 1.1.1.27) assays, one frozen at $-20{ }^{\circ} \mathrm{C}$ for protein content assay and another quickly frozen at $-80{ }^{\circ} \mathrm{C}$ for lipid peroxidation level (with a nitrogen flush). The supernatant from the second centrifuged aliquot was used for immediate cytochrome $c$ oxidase (CIV, EC 1.9.3.1) and NADH dehydrogenase and cytochrome $b c_{1}$ combined (CI-III, EC 1.6.5.3 and 1.10.2.2) assays.

\section{Physiological Measurements}

All enzymatic activities were expressed as $\mathrm{U} \mathrm{mg}^{-1}$ or $\mathrm{g}$ protein $^{-1}$. Total protein content was determined using the bicinchoninic acid method [29]. Enzyme activities were measured using a Lambda 11 UV/VIS spectrophotometer (Perkin-Elmer, MA, USA). Activities of CS and LDH, were assayed according to methods described in Thibeault et al. [30]. Activity of CI-III was measured according to the method described in Lannig et al. [31] while the activity of CIV was measured according to the method described in Pelletier et al. [32]. Enzymatic assays were conducted at 15 ${ }^{\circ} \mathrm{C}$. Conditions for enzyme assays are resumed in Table $\mathbf{1}$. Lipid peroxidation level (TBARS) was measured using a thiobarbituric acid reactive assay kit (OXItek TBARS Assay Kit; ZeptoMetrix Corporation, N.-Y., USA) in which MDA reacts with TBA substances under conditions of high temperature and acidity to generate a colored adduct that is measured spectrofluorometrically (F-2500 Fluorescence spectrophotometer, Hitachi Software Engineering America Ltd, CA, USA) [12].

\section{Statistical Analysis}

All statistical analyses were performed using SYSTAT (version 11.0, SPSS, 2004, Chicago, IL, USA). General linear model (GLM) was used and weight as a covariate to estimate the impact of family, temperature and age on enzyme activities and lipid peroxidation level. A second GLM was done omitting nonsignificant interaction(s) with weight. Tukey post-hoc test was used when significant differences were detected $(P<0.05)$. Normality of residuals was tested using Kolgomorov-Smirnov test with Lilliefors correction and homogeneities of variance were determined with Levene's test. To represent linear combinations between energy metabolism enzymes, lipid peroxidation level and weight, a principal component analysis (PCA) of all measured variables at the end of the experiment was also performed and to clear up linear relation between co-linear variables, partial correlations were made.

\section{RESULTS}

\section{mtDNA Divergence: ETS Coding Regions}

The overall nucleotide divergence between the two complete mtDNA genomes of $A$. minor and A. lupus is estimated at $2.0 \%$. Table 2 presents the comparison of the 13 proteincoding genes between Atlantic and spotted wolffish. The total nucleotide divergences ranged from $0.3 \%$ in the $n a d 3$ gene to $3.0 \%$ in the nad 4 gene, whereas the synonymous substitutions ranged from $0.6 \%$ in the atp 8 gene to $2.6 \%$ in the nad 1 gene. The transition to transversion ratio was highly variable among genes, ranging from 0 in the cox 3 , atp 8 and atp 6 genes to 40 in the $n a d 4$ gene.

A total of 23 amino acid substitutions occurred between both species. Except for $\operatorname{cox} 2, \operatorname{cox} 3$, atp 8 and $n a d 4 \mathrm{~L}$, all other genes showed amino acid substitutions. Three amino acid substitutions were observed for the cox 1 gene and one in the $c o b$ and atp 6 genes. The majority of amino acid differences was observed in genes of the NADH oxidoreductase complexe, nad4 (6), nad2 (4), nad5 (4), nad6 (2), nad1 (1) and nad 3 (1). Many genes (cox1, cob, nad2, nad4, nad5 and nad6) underwent nonconservative substitutions.

\section{Protein Content}

No difference in protein content of newly hatched larvae was detected for any sources of variation and this trend remained until the end of the experiment (results not shown).

\section{Mitochondrial Functions}

Since no significant temperature $\times$ family interactions were found for all physiological indicators (CI-III, CIV, CS, LDH, TBARS and CIV to CS ratio; Table 3), data from both temperatures groups were pooled. As a rough guide, mass of sampled fish (pooled temperatures) is shown in Fig. (1). Energy metabolism enzymes activities and oxidative stress indicators during the overall experimental period ( 0 to 90 DPH) are summarized in Fig. (2). Despite a significant interaction between family and age for the activity of the electron transport system (CI-III and CIV), no significant differences between families were observed at any age, except at 30 DPH for CI-III (SH1 > S1) (Fig. 2A,B; family $X$ age interaction, Table 3). CIV values significantly increased from hatching to $30 \mathrm{DPH}$ and afterwards stabilized until $90 \mathrm{DPH}$ for all families (Fig. 2B). No specific effect of hybridization and age was observed on CIV when the activity was expressed as a ratio of CS (Fig. 2E; family $X$ age interaction, Table 3). In contrast, CI-III values were stable through the experiment (Fig. 2A). The activity of the key tricarboxylic 
Table 2. Differences between the Mitochondrial Peptide-Coding Genes of Atlantic and Spotted Wolffish

\begin{tabular}{|c|c|c|c|c|c|c|c|c|c|c|c|}
\hline \multirow{3}{*}{ Gene } & \multirow{3}{*}{ Length } & \multicolumn{7}{|c|}{ Nucleotide Difference } & \multicolumn{3}{|c|}{ Amino Acid Substitution } \\
\hline & & \multirow[b]{2}{*}{$\mathbf{N}_{\mathbf{n}}$} & \multirow[b]{2}{*}{ Total (\%) } & \multirow[b]{2}{*}{$\mathbf{T}_{\mathrm{s}}$} & \multirow[b]{2}{*}{$\mathbf{T}_{\mathrm{v}}$} & \multirow[b]{2}{*}{$\mathbf{T}_{\mathrm{s}} / \mathbf{T}_{\mathrm{v}}$} & \multicolumn{2}{|c|}{ Syn. } & \multirow[b]{2}{*}{$\mathbf{N}_{\mathrm{a}}$} & \multirow[b]{2}{*}{ Total (\%) } & \multirow{2}{*}{$\begin{array}{c}\text { Noncon- } \\
\text { Servative } \\
(\%)\end{array}$} \\
\hline & & & & & & & nbr & $(\%)$ & & & \\
\hline $\operatorname{cox} 1$ & 1551 & 24 & 1.5 & 19 & 5 & 3.8 & 21 & 1.4 & 3 & 0.6 & 0.6 \\
\hline $\cos 2$ & 691 & 6 & 0.9 & 5 & 1 & 5 & 6 & 0.9 & 0 & 0 & 0 \\
\hline $\cos 3$ & 786 & 13 & 1.7 & 13 & 0 & - & 13 & 1.7 & 0 & 0 & 0 \\
\hline$c o b$ & 1141 & 25 & 2.2 & 24 & 1 & 24 & 24 & 2.1 & 1 & 0.3 & 0.3 \\
\hline $\operatorname{atp} 8$ & 168 & 1 & 0.6 & 1 & 0 & - & 1 & 0.6 & 0 & 0 & 0 \\
\hline atp6 & 684 & 6 & 0.9 & 6 & 0 & - & 5 & 0.7 & 1 & 0.4 & 0 \\
\hline$n a d 1$ & 975 & 26 & 2.7 & 24 & 2 & 12 & 25 & 2.6 & 1 & 0.3 & 0 \\
\hline nad2 & 1046 & 27 & 2.6 & 24 & 3 & 8 & 23 & 2.2 & 4 & 1.1 & 0.6 \\
\hline nad3 & 349 & 1 & 0.3 & 5 & 1 & 5 & 5 & 1.4 & 1 & 0.9 & 0 \\
\hline $\operatorname{nad} 4 \mathrm{~L}$ & 297 & 4 & 1.3 & 3 & 1 & 3 & 4 & 1.3 & 0 & 0 & 0 \\
\hline nad4 & 1381 & 41 & 3.0 & 40 & 1 & 40 & 35 & 2.5 & 6 & 1.3 & 0.9 \\
\hline nad5 & 1838 & 36 & 2.0 & 35 & 1 & 35 & 32 & 1.7 & 4 & 0.7 & 0.3 \\
\hline nad6 & 522 & 14 & 2.7 & 12 & 2 & 6 & 12 & 2.3 & 2 & 1.2 & 0.6 \\
\hline Total & & 224 & & 211 & 18 & & 206 & & 23 & & \\
\hline
\end{tabular}

$\mathrm{N}_{\mathrm{n}}$, total number of nucleotide differences; $\mathrm{N}_{\mathrm{a}}$, total number of amino acid differences; $\mathrm{T}_{\mathrm{s}}$, transition; $\mathrm{T}_{\mathrm{v}}$, transversion; Syn., synonymous substitutions.

Table 3. General Linear Model for Enzymatic Activities (CI-III, CIV, CS, LDH) and Lipid Peroxidation Level (TBARS) for the three wolffish Families (Non Significant Weight Interactions were Omitted in the Model)

\begin{tabular}{|c|c|c|c|c|c|c|c|c|c|c|c|c|c|}
\hline \multirow{2}{*}{ Source } & \multirow[t]{2}{*}{ df } & \multicolumn{2}{|c|}{ CI-III } & \multicolumn{2}{|c|}{ CIV } & \multicolumn{2}{|c|}{ CS } & \multicolumn{2}{|c|}{ LDH } & \multicolumn{2}{|c|}{ TBARS } & \multicolumn{2}{|c|}{ CIV to CS Ratio } \\
\hline & & $\mathbf{F}$ & $p$ & $\mathbf{F}$ & $p$ & $\mathbf{F}$ & $p$ & $\mathbf{F}$ & $p$ & $\mathbf{F}$ & $p$ & $\mathbf{F}$ & $p$ \\
\hline Family & 2 & 1.39 & 0.252 & 0.67 & 0.515 & 2.33 & 0.101 & 10.1 & 0.000 & 16.8 & 0.000 & 0.04 & 0.961 \\
\hline Age & 2 & 4.52 & 0.013 & 28.3 & 0.000 & 1.4 & 0.249 & 15.2 & 0.000 & 30.9 & 0.000 & 18.9 & 0.000 \\
\hline Temperature & 1 & 1.45 & 0.231 & 2.12 & 0.158 & 7.82 & 0.006 & 37.4 & 0.000 & 19.4 & 0.000 & 0.28 & 0.597 \\
\hline Weight & 1 & 0.04 & 0.834 & 0.03 & 0.861 & 7.37 & 0.007 & 0.69 & 0.409 & 4.81 & 0.030 & 3.55 & 0.062 \\
\hline Family $\times$ age & 4 & 5.38 & 0.000 & 2.56 & 0.042 & 2.10 & 0.084 & 7.33 & 0.000 & 7.45 & 0.000 & 5.81 & 0.000 \\
\hline Temperature $\times$ age & 2 & 1.39 & 0.252 & 0.93 & 0.399 & 0.31 & 0.733 & 40.5 & 0.000 & 11.3 & 0.000 & 0.41 & 0.666 \\
\hline Family $\times$ temperature & 2 & 0.78 & 0.462 & 0.95 & 0.391 & 0.33 & 0.719 & 0.57 & 0.566 & 0.12 & 0.887 & 0.43 & 0.652 \\
\hline Family $\times$ weight & 2 & - & - & 1.76 & 0.175 & - & - & - & - & 8.17 & 0.000 & - & - \\
\hline Age $\times$ weight & 2 & - & - & - & - & - & - & 6.18 & 0.003 & - & - & - & - \\
\hline
\end{tabular}

Independent variables were temperature $\left(8\right.$ and $\left.10^{\circ} \mathrm{C}\right)$, family $(\mathrm{S} 1, \mathrm{SH} 1$ and $\mathrm{SH} 2)$ and age $(0,30$ and $90 \mathrm{DPH})$. 


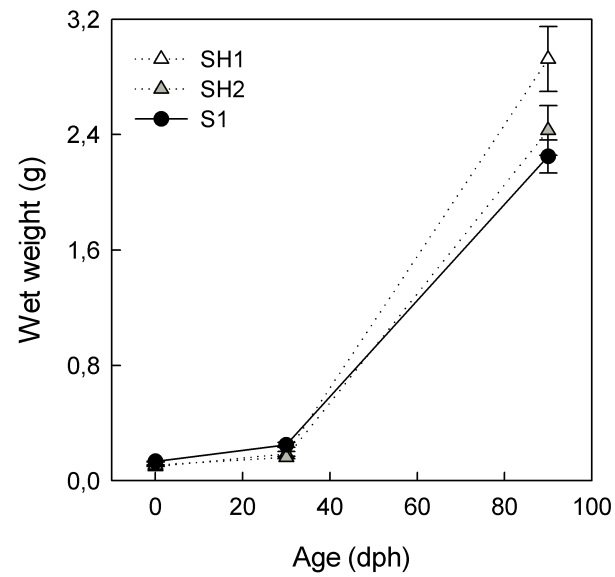

Fig. (1). Mean wet weight (g) of sampled fish of SH1 and SH2 (A. minor $\times$ A. lupus) and $\mathrm{S} 1$ (A. minor) families from 0 to $90 \mathrm{DPH}$ (mean \pm $\mathrm{SE}$ ). Data from both temperatures were pooled together.
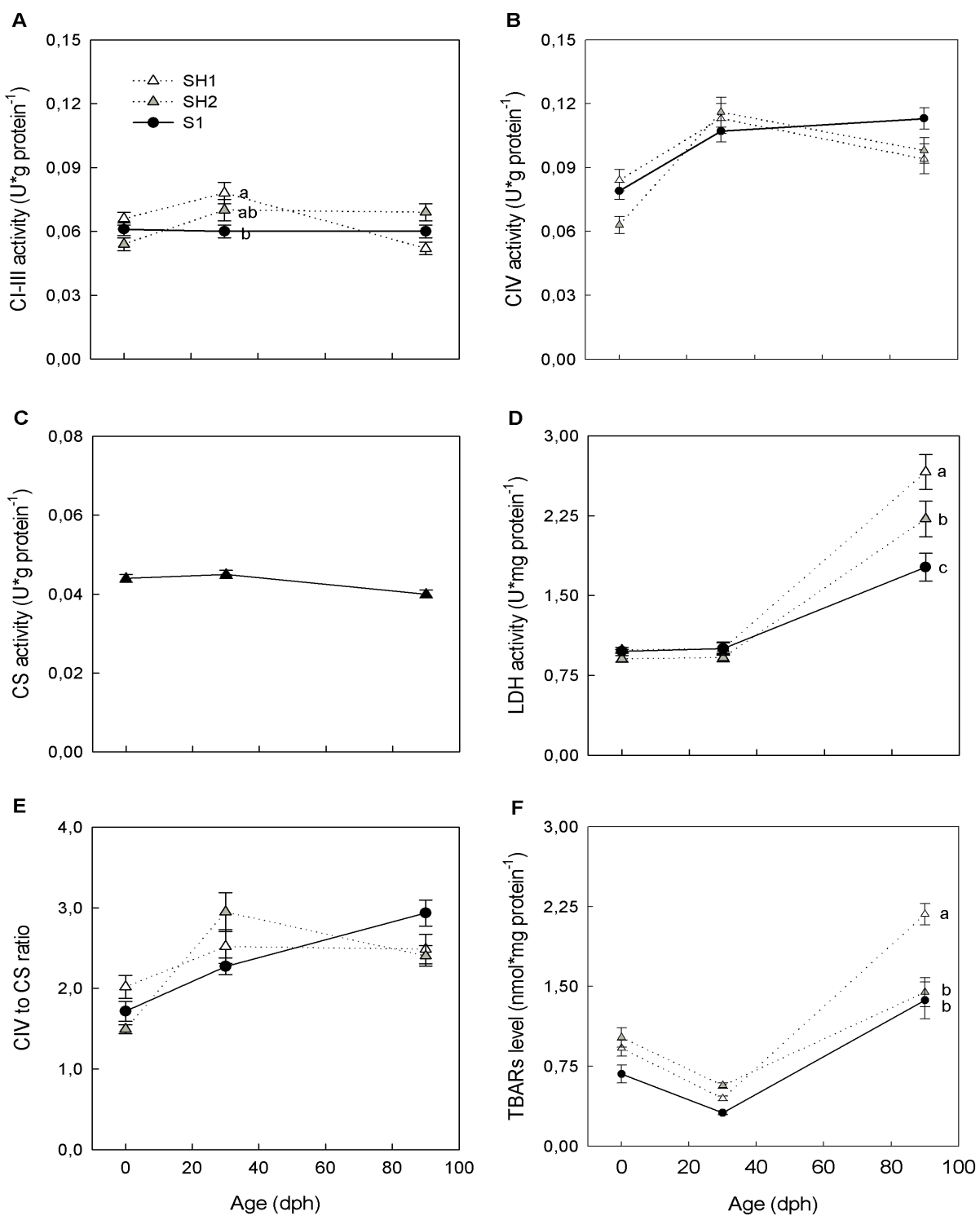

Fig. (2). Enzymatic activities of (A) NADH dehydrogenase and cytochrome $b c_{1}$ combined (CI-III), (B) cytochrome $c$ oxidase $(C I V)$, (C) citrate synthase $(C S),(\mathbf{D})$ lactate dehydrogenase $(L D H),(\mathbf{E})$ the lipid peroxidation level $(T B A R S)$ and $(\mathbf{F})$ the CIV to CS ratio $(C I V: C S)$ among wolffish families (SH1 and SH2, A. minor $\times$ A. lupus; $\mathrm{S} 1, A$. minor) from 0 to $90 \mathrm{DPH}$ (mean $\pm \mathrm{SE}$ ). Data from different temperatures and families were pooled together when these effects were not significant. $a, b, c$ indicate significant differences between families. 


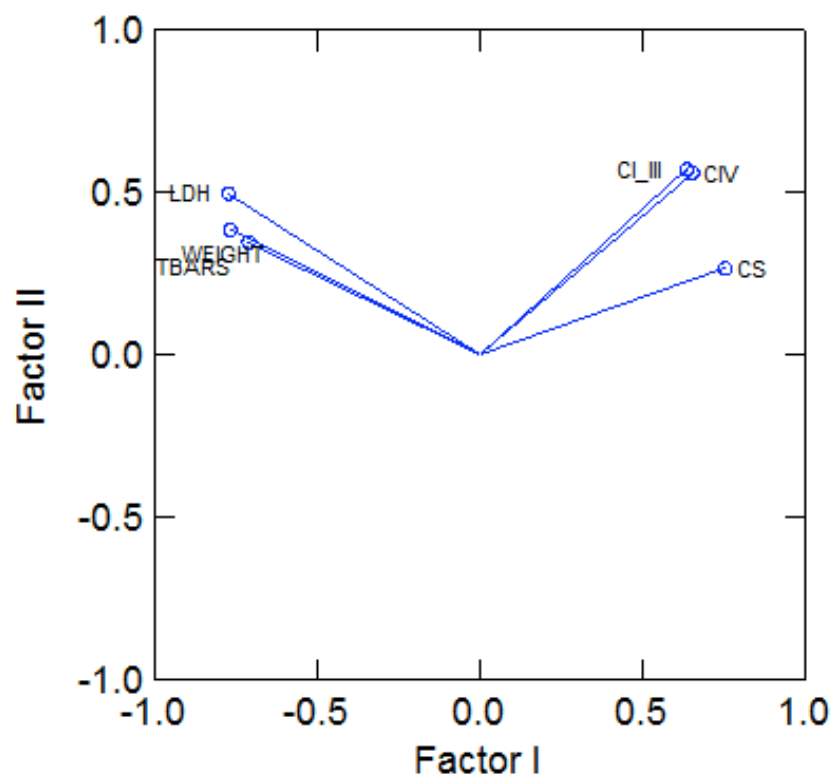

Fig. (3). Position of the vector-variables in the plan of the first two principal components (variance explained: 51.6 and $20.4 \%$ ). CI-III is for the activity of NADH dehydrogenase and cytochrome $b c_{1}$ combined, CIV is for the activity of cytochrome c oxidase, CS is for the activity of citrate synthase, LDH is for the activity of lactate dehydrogenase and TBARS is for lipid peroxidation level.

acid cycle enzyme (CS), was not affected by either family or age and no interaction between those two factors was detected (Fig. 2C; Table 3). Therefore, data from families were pooled together. All these family variations were independent of fish mass (family $X$ weight interaction, Table 3 ).

From hatching to $30 \mathrm{DPH}$, LDH activity stayed low for all families and increased afterwards until the end of the experiment (90 DPH) (Fig. 2D). However at $90 \mathrm{DPH}, \mathrm{LDH}$ activity for both spotted hybrid families were significantly higher compared to the pure control family (Fig. 2D; family $X$ age interaction, Table 3 ). Compared to the pure line, an increase, between 30 and $90 \mathrm{DPH}$, of 1.37-1.54 fold was observed among the hybrid families. The TBARS level decreased for all families from 0 to $30 \mathrm{DPH}$ and then increased until the end of the experience to reach higher values than at hatching (Fig. 2F). Like LDH activity, TBARS level were found significantly different between families at $90 \mathrm{DPH}$, but only SH1 showed a higher value (Fig. 2F; family $X$ age interaction, Table 3).

\section{Relationship between Energy Metabolism and Oxidative Stress}

A principal component analysis that combined the values of six variables into a single model: CI-III, CIV, CS and LDH activity, TBARS level and weight was realised (Fig. 3). The analysis extracted two components that explained $72.0 \%$ of the variability of the original data. The PCA clustered the dataset into two groups in which variables are positively interrelated 1) activity of the aerobic metabolism enzymes (CI-III, CIV and CS) and 2) lipid peroxidation level (TBARS), LDH activity and weight. To clear up the relation between lipid peroxidation level and LDH activity by taking off the effect of weight, a partial correlation was performed. The analysis lead to a strong linear relation between LDH and the oxidative stress indicator (TBARS level) $(\mathrm{r}=0.489$, $P<0.001)$ since controlling for weight did not lower the strength of the relationship between LDH and TBARS by that much (the outcome while not controlling for weight was $\mathrm{r}=0.637, P<0.001)$.

\section{DISCUSSION AND CONCLUSION}

\section{Mitochondrial Functions}

This study clearly demonstrates that hybridization does not affect the developmental pattern of the mitochondrial enzymes studied in F1 A. minor $\times$ A. lupus hybrid as no major distortion in the measured aerobic enzymatic profiles was observed between pure and hybrid lines. Some studies have demonstrated that amino acid substitutions may have an impact on nuclear-mitochondrial interactions and on the mechanisms regulating mitochondrial functioning $[1,2,33]$. Between the Atlantic and the spotted wolffish, most of amino acid substitutions are localized in the complex I genes (18) and others are in the complex III genes (1), the complex IV genes (3) and the complex V genes (1). These 23 nonsynonymous substitutions in lower numbers compared to the 47 found between the brook and the Arctic charr (45 in the complex I genes, one in the complex IV and the complex V) [34] that lead to minor impacts on the catalytic capacity of complexes I and IV of the hybrids [6]. Obviously, the level of divergence between $A$. minor and A. lupus $(2.0 \%)$ and the number of nonsynonymous substitutions do not seem to be sufficient to carry detectable differences in the catalytic capacities ETS complexes that we measured. This suggests that the $A$. minor $\times$ A. lupus hybrid is under the critical divergence threshold above which hybrid breakdown for these traits could be detected. For example, for murid xenomitochondrial hybrids to display a significant decrease in CIV activity, approximately 26 amino acid substitutions between mitochondrially encoded complex IV peptides of the nucleus donor species and the mtDNA donor species are needed according to McKenzie et al. [4]. In addition, hybridization unlikely affect the size and shape of mitochondria as shown by the CIV to CS activities ratio which may be associated 
with a change in the surface-volume ratio of mitochondria [35].

Highest values in LDH activity and lipid peroxidation level for wolffish hybrids seem not to be a response to hybridization but rather a response to fish mass. LDH profile linked to weigh is in accordance with previous studies on wolffishes and other species [36-41]. TBARS essay is an integrative parameter that quantified malonedialdehyde accumulation in tissues and our results suggest an allometric scaling of oxidative stress in the early life stages in fish. However, it is also possible that the weight relation concealed potential effects of hybridization status, but in light of our results, $A$. minor $\times A$. lupus hybrids seem to be physiologically robust and as the spotted pure line [41], they seem to rely on adequate metabolic capacities to sustain their high growth rate. Indeed, there was no clear reduction in performances or viability in the hybrids compared to the pure strain [23] when reared within optimal range temperature conditions.

This weak impact of mitochondrial haplotype on metabolic enzymes activity is corroborated by the absence of relation between hybridization and temperature responses. As previously cited, Blier et al. [6] evaluated functional properties of key mitochondrial enzyme in Arctic charr, brook charr and their hybrids and found no significant differences in enzymes activities even though these species evolved in different thermal environments. However, the limited scope of temperature acclimation used in this experiment does not provide reliable conclusions on specific physiological adaptations of $A$. minor $\times A$. lupus hybrid to cold and warm temperatures. We propose that if acclimation responses measured within viable thermal limits and those measured at extreme temperatures involved different factors it is possible that under sub-optimal conditions, hybridization between the spotted and Atlantic wolffish could limit the adaptability of the progeny. As cautioned by Blier et al. [6] it is also possible that the absence of differences is related to the difficulty of identifying and measuring the proper evolutionary or physiologically significant biochemical parameters.

In the present study we only crossed females $A$. minor with males $A$. lupus since the reverse cross gave poor condition and low viability offspring. This asymmetry in offspring viability from close species cross is also reported in other species [42]. This however does not invalidate the assumption that aerobic capacity and ETS functions should be impaired by broken co-adaptation of mitonuclear genomes which would have been detected by significant differences between hybrids and pure A. minor in the activity of enzymes from ETS.

\section{Oxidative Stress Management}

There was no detectable relationship between aerobic metabolism activities and lipid peroxidation level, but rather a strong relationship with LDH activity. This is clearly illustrated by parallel pattern of LDH activity and TBARS levels among groups and during early development. Here we cannot tell if higher LDH activity and TBARS level in SH1 at $90 \mathrm{dph}$ is linked to hybridization process or simply dictated by potentially higher anaerobic capacity of $A$. lupus, but in any case TBARS levels appear to be tightly linked to total
LDH activity. Lactate dehydrogenase, that catalyzes pyruvate-lactate conversion, regulates levels of cytosolic NADH and thus NAD/NADH ratio. NAD/NADH and NADP/NADPH ratios have an important implication in oxidative stress management as they play key roles in cellular antioxidation capacity and ROS generation (reviewed by [43]). In addition to be linked to the cellular reducing potential, NADH, via NADPH, promote glutathione (GSH) regeneration, which is required for the activities of the antioxidant enzymes glutathione peroxidise (GPx) and glutathione-Stransferases (GST).

Our results could suggest an important function of $\mathrm{LDH}$ enzyme in oxidative stress management probably via management of cytoplasmic redox potential $\left(\mathrm{NADH} / \mathrm{NAD}^{+}\right)$. In clear, increase in LDH activity (mostly muscular LDH) could shift the redox equilibrium to a lower NADH/NAD ${ }^{+}$ ratio impairing $\mathrm{GSH}$ regeneration through diminution of NADPH content. This explanation however has to be tested, but our observations could be an important contribution to the interpretation of the evolutionary significance of $\mathrm{LDH}$ adaptation to different environments. Our comparisons between pure $A$. minor and hybrids, which surprisingly showed low divergences in aerobic capacity, revealed an important level of variation among fish in anaerobic capacity. The high level of variability reached by using hybridization, enabled us to establish a clear relationship between $\mathrm{LDH}$ and TBARS likely through regulation of cytoplasmic redox state.

\section{ACKNOWLEDGMENTS}

The authors thank the following people for their help in various aspects of this study: T. Grenier, D. Ouellet and A. Savoie from UQAR and G. Parent (U. Laval). Special thanks to R. Vergilino (UQAR) for sequences comparison analysis. This study was supported by grants from AquaNet (AP-34), FQRNT and the MAPAQ to NLF and PB. CG was awarded grants from CSMOPM, FUQAR and RAQ.

\section{REFERENCES}

[1] Blier PU, Dufresne F, Burton RS. Natural selection and the evolution of mtDNA-encoded peptides: evidence for intergenomic coadaptation. Trends Genet 2001; 17: 400-6.

[2] Ellison CK, Burton RS. Disruption of mitochondrial function in interpopulation hybrids of Tigriopus californicus. Evolution 2006; 60: 1382-91.

[3] Sackton TB, Haney RA, Rand DM. Cytonuclear coadaptation in Drosophilia: disruption of cytochrome c oxidase activity in backcross genotypes. Evolution 2003; 57: 2315-25.

[4] McKenzie M, Chiotis M, Pinkert CA, Trounce IA. Functional respiratory chain analyses in murid xenomitochondrial cybrids expose co-evolutionary constraints of cytochrome $b$ and nuclear subunits of complex III. Mol Biol Evol 2003; 20: 1117-24.

[5] Holland LZ, McFall-Ngai M, Somero GN. Evolution of lactate dehydrogenase-A homologs of barracuda fishes (Genus sphyraena) from different thermal environments: Differences in kinetic properties and thermal stability are due to amino acid substitutions outside the active site. Biochemistry 1997; 36: 3207-15.

[6] Blier PU, Breton S, Desrosiers V, Lemieux H. Functional conservatism in mitochondrial evolution: insight from hybridization of Arctic and Brook charrs. J Exp Zool 2006; 306: 1-8.

[7] Heise K, Puntarulo S, Pörtner HO, Abele D. Production of reactive oxygen species by isolated mitochondria of the Antarctic bivalve Laternula elliptica (King and Broderip) under heat stress. Comp Biochem Physiol 2003; 134: 79-90.

[8] Sohal RS, Arnold L, Orr WC. Effect of age on superoxide dismutase, catalase, glutathione reductase, inorganic peroxides, TBA- 
reactive material, GSH/GSSG, NADPH/NADP and NADH/NAD in Drosophila melanogaster. Mech Ageing Dev1990; 56: 223-35.

[9] Barja G. Mitochondrial free radical production and aging in mammals and birds. Ann NY Acad Sci 1998; 854: 224-38.

[10] Pamplona R, Barja G. An evolutionary comparative scan for longevity-related oxidative stress resistance mechanisms in homeotherms. Biogerontology 2011; 12: 409-35.

[11] Sies H. Oxidative stress: introduction. In: Sies H, Ed. Oxidative Stress: oxidants and antioxidants San Diego: Academic Press 1991; pp. 21-48.

[12] Almroth BC, Sturve J, Berglund A, Forlin L. Oxidative damage in eelpout (Zoarces viviparous), measured as protein carbonyls and TBARS, as biomarkers. Aquat Toxicol 2005; 73: 171-80.

[13] Luschak VI, Bagnyukova TV. Temperature increase results in oxidative stress in goldfish tissues. 1. Indice of oxidative stress. Comp Biochem Physiol C 2006; 143: 30-5.

[14] Abele D, Heise K, Pörtner HO, Puntarulo S. Temperaturedependence of mitochondrial function and production of reactive oxygen species in the intertidal mud clam Mya arenaria. J Exp. Biol 2002; 205: 1831-41.

[15] Le François NR, Lemieux H, Blier PU. Biological and technical evaluation of the potential of marine and anadromous fish species for cold-water mariculture. Aquacult Res 2002; 33: 95-108.

[16] Foss A, Imsland AK, Falk-Petersen IB, Oiestad V. A review of the culture of spotted wolffish Anarhichas minor Olfasen. Rev Fish Biol Fish 2004; 14: 277-94.

[17] Johnstone KA, Marshall HD, Carr SM. Biodiversity genomics for species at risk: patterns of DNA sequence variation within and among complete mitochondrial genomes of three species of wolffish (Anarhichas spp.). Can J Zool 2007; 85: 151-8.

[18] Kulka D, Hood C, Huntington J. Recovery strategy for Northern wolffish (Anarhichas denticulatus) and spotted wolffish (Anarhichas minor), and management plan for Atlantic wolffish (Anarhichas lupus) in Canada. Fisheries and Oceans Canada: Newfoundland and Labrador region. St-John's (NL); 2007 Available from: http://www.sararegistry.gc.ca [Accessed 11th sept. 2011].

[19] Luhmann M. Uber intermediare Formen zwischen Anarhichas minor Olafsen. und A. lupus L. (Teleostei). Ber. Dtsch. Wiss. Komm. Meeresforsch 1954; 13: 310-26.

[20] BarsukovVV. The wolffish (Anarhichadidae). Springfield: Smithsonian Institute NTIS 1972.

[21] Templeman W. Spotted Forms of the Northern Wolffish (Anarhichas denticulatus). J Northwest Atl Fish Sci 1986; 7: 77-80.

[22] Imsland AK, Stensland K, Johansen T, et al. Genetic population structure of the spotted wolf fish, Anarhichas minor in the North Atlantic. Open J Mar Biol 2008; 2: 7-12.

[23] Gaudreau CM, Le François NR, Ditlecadet D, Tveiten H, Blier PU. Characterization of the early-stages of the wolffish hybrid Anarhichas minor $\times$ A. lupus: conservation and aquaculture applications. Aquat Liv Resour 2009; 22: 371-7.

[24] McCarthy ID, Moksness E, Pavlov DA, Houlihan DF. Effects of water temperature on protein synthesis and protein growth in juvenile Atlantic wolffish (Anarhichas lupus). Can J-Fish Aquat Sci 1999; 56: 231-41.

[25] Imsland AK, Foss A, Sparboe LO, Sigurdsson S. The effect of temperature and fish size on growth and feed efficiency ratio of juvenile spotted wolffish Anarhichas minor. J Fish Biol 2006; 68: $1107-22$.
[26] Hall TA. BioEdit: a user-friendly biological sequence alignment editor and analysis program for Windows 95/98/NT. Nucl Acids Symp Ser 1999; 41: 95-8.

[27] Kumar S, Tamura K, Nei M. MEGA: molecular evolutionary genetics analysis. Version 1.01. University Park: Pennsylvania State University 1993.

[28] Moksness E, Pavlov DA. Management by life cycle of wolffish, Anarhichas lupus L., a new species for cold-water aquaculture: a technical paper. Aquacult Res 1996; 27: 865-83.

[29] Smith PK, Krohn RI, Hermanson GT, et al. Measurement of protein using bicinchoninic acid. Ann Biochem 1985; 150: 76-85.

[30] Thibeault M, Blier PU, Guderley H. Seasonal variation of muscle metabolic organization in rainbow trout (Oncorhynchus mykiss). Fish Physiol Biochem 1997; 16: 139-55.

[31] Lannig G, Eckerle LG, Serendero I, et al. Temperature adaptation in eurythermal cod (Gadus morhua): a comparison of mitochondrial enzyme capacities in boreal and Arctic populations. Mar Biol 2003. 142: 589-99.

[32] Pelletier D, Guderley H, Dutil J-D. Does aerobic capacity of fish muscle change with growth rates? Fish Physiol Biochem 1993; 12: 83-93.

[33] Ellison CK, Burton RS. Interpopulation hybrid breakdown maps to the mitochondrial genome. Evolution 2008; 62: 631-8

[34] Doiron S, Bernatchez L, Blier PU. A comparative mitogenomic analysis of the potential adaptive value of Arctic charr mtDNA introgression in brook charr populations (Salvelinus fontinalis Mitchill). Mol Biol Evol 2002; 19: 1902-9.

[35] Pelletier D, Blier PU, Dutil J-D, Guderley H. How should enzymeactivities be used in fish growth studies? J Exp Biol 1995; 198: 1493-7.

[36] Somero GN, Childress JJ. A violation of the metabolism-size scaling paradigm: activities of glycolytic enzymes in muscle increase in larger-size fish. Physiol Zool 1980; 53: 322-37.

[37] Martinez M, Dutil JD, Guderley H. Longitudinal and allometric variation in indicators of muscle metabolic capacities in Atlantic cod (Gadus morhua). J Exp Zool 2000; 287: 38-45.

[38] Lemieux H, Le François NR, Blier PU. The early ontogeny of digestive and metabolic enzyme activities in two commercial strains of Arctic charr (Salvelinus alpinus L.). J Exp Zool A 2003; 299: 151-60.

[39] Lamarre SG, Le François NR, Falk-Petersen I-B, Blier PU. Can digestive and metabolic enzyme activity levels predict growth rate and survival of newly hatched Atlantic wolffish (Anarhichas lupus Olafsen)? Aquacult Res 2004; 35: 608-13.

[40] Lamarre SG, Le François NR, Lemieux H, Falk-Petersen I-B, Blier PU. The digestive and metabolic enzyme activity profiles of a nonmetamorphic marine fish species: effects of feed and feeding level. Can J Fish Aquat Sci 2007; 64: 849-56.

[41] Savoie A, Le François NR, Cahu C, Blier PU. Metabolic and digestive enzyme activity profiles of newly hatched spotted wolffish (Anarhichas minor Olafsen): effect of temperature. Aquacult Res 2008; 39: 382-9.

[42] Glémet H, Blier P, Bernatchez L. Geographical extent of arctic charr (Salvelinus alpinus) mtDNA introgression in brook char populations (S. fontinalis) from eastern Quebec, Canada. Mol Ecol 1998; 7: 1655-62.

[43] Ying W. NAD ${ }^{+} / \mathrm{NADH}$ and $\mathrm{NADP}^{+} / \mathrm{NADPH}$ in cellular functions and cell death: regulation and biological consequences. Antioxid Redox Sig 2008; 10: 179.

(C) Gaudreau et al.; Licensee Bentham Open.

This is an open access article licensed under the terms of the Creative Commons Attribution Non-Commercial License (http://creativecommons.org/licenses/ by-nc/3.0/) which permits unrestricted, non-commercial use, distribution and reproduction in any medium, provided the work is properly cited. 